$\begin{gathered}\text { EPiC Series in Built Environment } \\ \text { Volume 2, 2021, Pages 100-107 } \\ \text { ASC 2021. 57th Annual Associated Schools } \\ \text { of Construction International Conference }\end{gathered}$
Built
Environment

\title{
Investigation of Skill Sets for Multiskilled Labor Development in Construction
}

\author{
Heung Jin Oh and Baabak Ashuri, Ph.D., P.E. \\ Georgia Institute of Technology \\ Atlanta, Georgia
}

\author{
Soowon Chang, Ph.D. \\ Purdue University \\ West Lafayette, IN
}

The major objective of this research is to investigate construction job market for developing multiskilled labor in the construction industry using web scraping and text mining techniques. The construction industry has been suffered from the skilled labor shortage. To resolve the shortage and pertinent problems, multiskilled labor utilization strategies have been presented in construction. Although extensive research has been conducted over multiskilling strategies, it is still uncertain what skill sets are desirable to foster and utilize multiskilled labor efficiently in construction projects. To fill the gap, this research investigates skill sets for multiskilled labor development in construction using web scraping technique. We analyze texts of companies' job openings and provide the latest trends in what skill sets are beneficial for workers to get employed. The results provide skilled labor with the information of what kind of skill sets required to meet industrial needs. This research will contribute to the body of knowledge by expanding the multiskilling strategies through the data-driven analysis of real construction job market.

Key Words: Skilled Labor Shortage, Multiskilled Labor, Job Posting, Text Mining, Web Scraping

\section{Introduction}

Skilled labor shortages have become a significant issue in the construction industry. The shortages can cause construction delays and rework, cost overruns, and even safety issues in construction projects (Kim, Chang, \& Castro-Lacouture, 2020). Meanwhile, the scarcity of skilled labor will be more severe due to the increase of retirement of construction laborers (McKinsey \& Company, 2020). In order to reduce the craft shortages, research has been conducted to better utilize workforce by multiskilling and cross-training existing laborers. The multiskilling strategies can develop workforce competency as well as continuously utilize the workforce's capabilities throughout projects in a managerial perspective (Burleson, Haas, Tucker, \& Stanley, 1998). Also, multiskilled labor can provide a higher productivity by better understanding the entire process (Carley, Haas, Borcherding, \& Goodrum, 2003; Haas, Rodriguez, Glover, \& Goodrum, 2001). Therefore, multiskilled laborers can not only secure their jobs better but also increase their employment duration more than single-skilled laborers (Gomar, Haas, \& Morton, 2002). 
Although previous research has studied the multiskilling strategies that skill set configuration is desirable or efficient is still unclear. Previous studies have been conducted on which skill sets are lacking and how multiskilled labor should be applied to solve the shortage of skilled workers. These studies included case studies, interviews, and implementations, such as algorithms which can improve multiskilled labor utilization. For example, Burleson et al.(1998) explained how to measure the potential benefits of multiskilled labor at project level based on survey (Burleson et al., 1998). Hass et al. (2001) proposed workflows implementing multiskilled labor in three different phases of company, bid-preparation, and project planning and construction phases based on personal and telephone interviews (Haas et al., 2001). Wang et al. (2009) analyzed skill affinity patterns and motivations using Pearson correlation between any of the two craft skills for NCACP and CII data sets (National Craft Assessment and Certification Program; Construction Industry Institute) (Wang, Goodrum, Haas, \& Glover, 2009). On the other hand, research has broaden its scope by investigating how to improve scheduling algorithms for efficient utilization of multiskilled labor (Wongwai \& Malaikrisanachalee, 2011) and how to optimally allocate tasks in prefabricated construction to multiskilled labor using case studies (Nasirian, Arashpour, Abbasi, \& Akbarnezhad, 2019). However, previous studies have limited to sample data collected by surveys or case studies, the skill set configurations can be biased to the samples. Even if NCACP and CII data were analyzed, the skill affinity patterns from the historical data could not be updated over time by considering recent trends or changes in multiskilling.

In this respect, this research aims to investigate construction job market that can guide skilled laborers to develop multiple skill sets required by recent companies' needs. Today, online job posting has enabled construction workers to find job vacancies as well as identify skill requirements in real time. This research hypothesized that online job postings contain types of multiple skills needed in the construction industry. Publicly available construction job information posted on Indeed (https://www.indeed.com/) is utilized to collect current needs of skill sets throughout the United States. Using a web scraping, texts in job description were analyzed. Therefore, this study identifies sets of skills that are related to each other based on job duties provided by the job announcements and provides multiskilling or cross-training strategies. The findings will contribute to supporting the development of multiskilled labor in construction.

\section{Methodology}

Web scraping is data extracting from websites. This research conducted scraping job postings from Indeed, an employment website for job listings to collect data related to construction jobs. Construction job postings were obtained in .csv format using the web scraping code. The code was formulated using R programming language. Microsoft Excel was used to categorize job lists by types of skilled labor based on the Occupational Outlook Handbook provided by the U.S. BLS (U.S. Bureau of Labor Statistics, 2020)

\section{Web Scraping and Text Trimming}

R code for web scraping was formulated to search "construction"-related jobs and collect job titles, job descriptions, and locations within the U.S. Among data collected, job titles and job descriptions were used to identify which skills are required for a specific job posting. Web scraping collected data daily base from the end of April to the beginning of October 2020, and a unique ID was given to each job posting. All overlapped postings were eliminated in the process of integrating the scraped data. Text trimming was performed to obtain the information needed to classify the skill sets from the 
integrated data. Redundant marks in the texts, such as symbols and special characters, were removed and all characters were changed to the lower case for further data processing. $R$ packages such as "rvest", "stringr", and "tidyverse" were mainly used for this research.

\section{Identifying and Categorizing Skills on Job Postings}

To standardize a range of skill sets in construction, this research first identified a list of skilled labor. According to the U.S. BLS, types of construction skilled labor were found in the "Construction and Extraction Occupations" group, and all types except "Construction Laborers and Helpers" were considered as skilled labor. Based on the task descriptions on the U.S. BLS, the authors found that welders in the "Production Occupations" group are often required in tasks of ironworkers. Also, Heating, Air Conditioning, and Refrigeration (HVACR) Mechanics and Installers in the "Installation, Maintenance, and Repair Occupations" group often support ductwork installed by sheet metal workers, electrical tasks by electricians, pipework by plumbers, and boiler systems by boilermakers. Therefore, categorization of skilled labor for the construction industry were identified into 19 individual skills within three (3) occupation groups. The dataset from the web scraping was categorized into the 19 types of skills based on keywords presented in table 1 . The keywords were defined based on job duties on the U.S. BLS. Text data from web scraping was mapped to the groups of skilled labor presented in table 1 .

Table 1

Categorization of skilled labor for the construction industry (Adapted from data provided by the U.S. Bureau of Labor Statistics, 2020)

\begin{tabular}{|c|c|c|c|}
\hline $\begin{array}{l}\text { Occupation } \\
\text { Groups }\end{array}$ & Skilled Labor & Keywords & $\begin{array}{l}\text { Abbrev } \\
\text { iations }\end{array}$ \\
\hline Production & $\begin{array}{l}\text { Welders, Cutters, } \\
\text { Solderers, and Brazers }\end{array}$ & $\begin{array}{l}\text { welder; "metal"\&"cutter"; solderer; brazer; } \\
\text { soldering brazing; brazing; soldering }\end{array}$ & WL \\
\hline \multirow{10}{*}{$\begin{array}{l}\text { Construction } \\
\text { and Extraction } \\
\text { Occupations }\end{array}$} & Boilermakers & boilermaker; boiler & $\mathrm{BM}$ \\
\hline & Carpenters & carpent; wood floor & $\mathrm{CP}$ \\
\hline & $\begin{array}{l}\text { Construction and } \\
\text { Building Inspectors }\end{array}$ & inspect; examiner & $\mathrm{I}$ \\
\hline & $\begin{array}{l}\text { Construction } \\
\text { Equipment Operators }\end{array}$ & $\begin{array}{l}\text { operator (Excluded "warehouse operator", } \\
\text { "plant operator", "accounting operator", and } \\
\text { quality operator".) }\end{array}$ & OP \\
\hline & $\begin{array}{l}\text { Drywall Installers, } \\
\text { Ceiling Tile Installers, } \\
\text { and Tapers }\end{array}$ & $\begin{array}{l}\text { drywall installer; drywaller; hanger; } \\
\text { acoustical carpenter; ceiling tile installer; } \\
\text { taper; finisher (Excluded "concrete finisher") }\end{array}$ & DW \\
\hline & Electricians & electrician; electric technician; electrical & EL \\
\hline & $\begin{array}{l}\text { Elevator and Escalator } \\
\text { Installers and Repairers }\end{array}$ & elevator; escalator & ES \\
\hline & $\begin{array}{l}\text { Flooring Installers and } \\
\text { Tile and Marble Setters }\end{array}$ & $\begin{array}{l}\text { flooring installer; tile setter; marble setter; } \\
\text { carpet installer; tile installer; floor sander; } \\
\text { vinyl installer; tile finisher }\end{array}$ & FL \\
\hline & Glaziers & glazier & $\mathrm{G}$ \\
\hline & $\begin{array}{l}\text { Hazardous Materials } \\
\text { Removal Workers }\end{array}$ & $\begin{array}{l}\text { asbestos abatement worker; lead abatement } \\
\text { worker; hazardous material }\end{array}$ & $\mathrm{HM}$ \\
\hline
\end{tabular}




\begin{tabular}{|c|c|c|c|}
\hline & Ironworkers & $\begin{array}{l}\text { ironworker; steel worker; rebar worker; steel } \\
\text { erector }\end{array}$ & IR \\
\hline & Masonry Workers & $\begin{array}{l}\text { masonry; stonemason; cement mason; } \\
\text { concrete finisher; terrazzo }\end{array}$ & MS \\
\hline & $\begin{array}{l}\text { Painters, Construction } \\
\text { and Maintenance }\end{array}$ & painter; plasterer; paperhanger & $\mathrm{P}$ \\
\hline & $\begin{array}{l}\text { Plumbers, Pipefitters, } \\
\text { and Steamfitters }\end{array}$ & plumber; steamfitter; fitter; solar thermal & PL \\
\hline & Roofers & roofer & RF \\
\hline & Sheet Metal Workers & sheet meter; sheetmetal & SHM \\
\hline & $\begin{array}{l}\text { Solar Photovoltaic } \\
\text { Installers }\end{array}$ & pv installer; solar panel, solar pv & PV \\
\hline $\begin{array}{c}\text { Installation, } \\
\text { Maintenance, } \\
\text { and Repair } \\
\text { Occupations }\end{array}$ & $\begin{array}{l}\text { Heating, Air } \\
\text { Conditioning, and } \\
\text { Refrigeration } \\
\text { Mechanics and } \\
\text { Installers }\end{array}$ & $\begin{array}{l}\text { heating; air conditioning; hvac; refrigeration; } \\
\text { solar thermal }\end{array}$ & HR \\
\hline
\end{tabular}

\section{Results}

After categorizing skills on job postings, this study identified that types of skilled labor are required for a specific job posting. Among 901,885 construction job postings, 228,242 jobs required skilled laborers (25\% of postings). Among them, 218,057 jobs were for hiring single-skilled laborers, and the 5 most frequent job postings were for equipment operators, electricians, carpenters, plumbers, and welders in turn (figure 1). Among job postings looking for skilled laborers, 9,730 jobs were for seeking dual-skilled laborers (or two types of skilled laborers), and 455 jobs required more than two types of skilled laborers. The skill set configurations which were posted on the same job postings were analyzed to guide how to develop multiskilled labor based on the industrial needs.

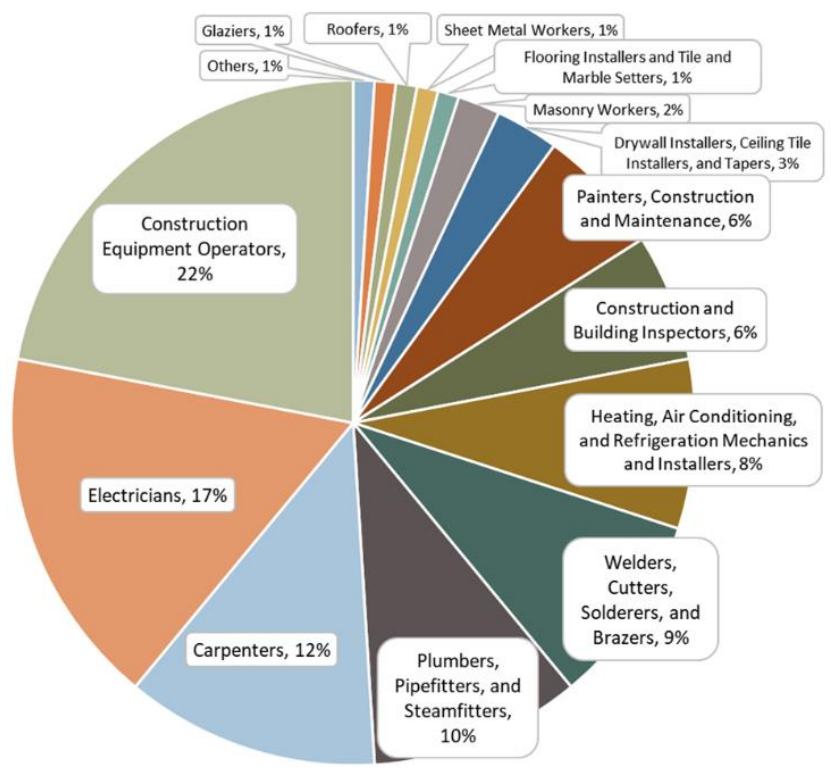

Figure1. Job postings looking for single-skilled laborers 


\section{Multiskilling Strategies}

Strategies for developing multiskilled labor are presented in the following sections. The strategies will guide skilled laborers to develop multiple skill sets to meet construction companies' needs.

\section{Strategies for Dual Skill Set Configurations}

The most frequent three combinations of dual skills explained $50 \%$ of job posting requiring dual skills. Considering frequencies of combined skill sets, 3,487 job postings were for masonry works and drywall installers at the same time. Also, 1,498 job postings were requiring the skills for welders, cutters, solderers, and brazers as well as skills for plumbers, pipefitters, and steamfitters. Then, more than 600 jobs required HVACR mechanics and installers and sheet metal workers together.

Frequencies of job posting requiring two skill sets are shown in figure 2 and table 2. For drywallers, developing skills for masonry, painter, or carpentry will be attractive for getting employed in construction companies. For carpenters, skills related to drywallers, masonry, or painter can have benefits to get a job. For plumbers, if they develop skills for welders or HVACR mechanics and installers, multiskilled plumbers would be more likely to be hired. For electricians, they will broaden the hiring opportunities by developing skills related to inspectors.

\begin{tabular}{|c|c|c|c|c|c|c|c|c|c|c|c|c|c|c|c|c|c|c|c|}
\hline & BM & $\mathrm{CP}$ & $I$ & OP & DW & EL & ES & $\mathrm{FL}$ & $\mathbf{G}$ & HM & IR & MS & $\mathbf{P}$ & $\mathrm{PL}$ & RF & SHM & PV & HR & $W L$ \\
\hline BM & & & 15 & 79 & 1 & 3 & & & & & & & & 26 & & 1 & & 32 & 26 \\
\hline $\mathrm{CP}$ & & & 3 & 32 & 475 & 100 & & 106 & 41 & & 23 & 497 & 391 & 109 & 123 & 15 & 1 & 18 & 34 \\
\hline I & & & & 96 & 8 & 372 & 75 & & & 3 & & 12 & 4 & 10 & & 9 & & 29 & 10 \\
\hline OP & & & & & 66 & 82 & 41 & 1 & & 1 & 8 & 31 & 40 & 63 & 1 & 53 & 1 & 26 & 289 \\
\hline DW & & & & & & 1 & & 59 & 1 & & 2 & 3487 & 541 & 3 & 19 & 4 & & 1 & 25 \\
\hline EL & & & & & & & 3 & 1 & & & 2 & & 10 & 125 & 22 & & 19 & 249 & 31 \\
\hline ES & & & & & & & & & & & & & & & & & & & 1 \\
\hline FL & & & & & & & & & & & & 3 & 7 & 5 & 1 & & & & \\
\hline G & & & & & & & & & & & & & 1 & & 1 & & & & \\
\hline \multicolumn{20}{|l|}{ HM } \\
\hline IR & & & & & & & & & & & & 1 & 1 & 5 & 2 & 4 & & & 119 \\
\hline MS & & & & & & & & & & & & & 8 & 1 & 13 & 1 & & & \\
\hline $\mathbf{P}$ & & & & & & & & & & & & & & 17 & 36 & 3 & & 3 & 40 \\
\hline PL & & & & & & & & & & & & & & & 16 & 42 & 2 & 392 & 1498 \\
\hline $\mathbf{R F}$ & & & & & & & & & & & & & & & & 107 & 12 & 14 & 2 \\
\hline SHM & & & & & & & & & & & & & & & & & & 614 & 95 \\
\hline PV & & & & & & & & & & & & & & & & & & 1 & \\
\hline HR & & & & & & & & & & & & & & & & & & & 34 \\
\hline WL & & & & & & & & & & & & & & & & & & & \\
\hline
\end{tabular}

Figure2. Frequencies of job posting requiring two skill sets 
Table 2

Top 20 frequent dual skill set configurations

\begin{tabular}{l|l|c}
\hline Skill Set 1 & Skill Set 2 & $\begin{array}{c}\text { Number of } \\
\text { Postings }\end{array}$ \\
\hline Masonry Workers & $\begin{array}{l}\text { Drywall Installers, Ceiling Tile } \\
\text { Installers, and Tapers }\end{array}$ & 3487 \\
\hline Welders, Cutters, Solderers, and Brazers & Plumbers, Pipefitters, and Steamfitters & 1498 \\
\hline $\begin{array}{l}\text { Heating, Air Conditioning, and } \\
\text { Refrigeration Mechanics and Installers }\end{array}$ & Sheet Metal Workers & 614 \\
\hline Painters, Construction and Maintenance & $\begin{array}{l}\text { Drywall Installers, Ceiling Tile } \\
\text { Installers, and Tapers }\end{array}$ & 541 \\
\hline Masonry Workers & Carpenters & 497 \\
\hline $\begin{array}{l}\text { Drywall Installers, Ceiling Tile } \\
\text { Installers, and Tapers }\end{array}$ & Carpenters & 475 \\
\hline $\begin{array}{l}\text { Heating, Air Conditioning, and } \\
\text { Refrigeration Mechanics and Installers }\end{array}$ & Plumbers, Pipefitters, and Steamfitters & 392 \\
\hline Painters, Construction and Maintenance & Carpenters & 391 \\
\hline Electricians & Construction and Building Inspectors & 372 \\
\hline Welders, Cutters, Solderers, and Brazers & Construction Equipment Operators & 289 \\
\hline $\begin{array}{l}\text { Heating, Air Conditioning, and } \\
\text { Refrigeration Mechanics and Installers }\end{array}$ & Electricians & 249 \\
\hline Plumbers, Pipefitters, and Steamfitters & Electricians & 125 \\
\hline Roofers & Carpenters & 123 \\
\hline Welders, Cutters, Solderers, and Brazers & Ironworkers & 119 \\
\hline Plumbers, Pipefitters, and Steamfitters & Carpenters & 109 \\
\hline Sheet Metal Workers & Roofers & 107 \\
\hline $\begin{array}{l}\text { Flooring Installers and Tile and Marble } \\
\text { Setters }\end{array}$ & Carpenters & 106 \\
\hline Electricians & Carpenters & 96 \\
\hline Construction Equipment Operators & Construction and Building Inspectors & 95 \\
\hline Welders, Cutters, Solderers, and Brazers & Sheet Metal Workers & \\
\hline & & \\
\hline
\end{tabular}

\section{Strategies Triple Skill Set Configurations}

Strategies of developing three skill sets are presented in this section. About $74 \%$ of triple skill set configurations were explained by top 9 configurations of triple skill set, which were posted more than or equal to 10 times (see table 3). Multiskilled laborers possessing skills of carpenters and drywallers can be exposed more job opportunities when they are developing skills related to masonry workers, painters, or flooring installers. Plumbers having skills for HVACR mechanics and installers can develop skill sets for welders or electricians to be more attractive in the construction job market. 
Table 3

Three skill set configurations posted on more than 10 job postings

\begin{tabular}{|c|c|c|c|}
\hline Skill Set 1 & Skill Set 2 & Skill Set 3 & $\begin{array}{c}\text { Number of } \\
\text { Postings }\end{array}$ \\
\hline Carpenters & $\begin{array}{l}\text { Drywall Installers, Ceiling } \\
\text { Tile Installers, and Tapers }\end{array}$ & Masonry Workers & 152 \\
\hline Carpenters & $\begin{array}{l}\text { Drywall Installers, Ceiling } \\
\text { Tile Installers, and Tapers }\end{array}$ & $\begin{array}{l}\text { Painters, Construction and } \\
\text { Maintenance }\end{array}$ & 42 \\
\hline Carpenters & Electricians & $\begin{array}{l}\text { Plumbers, Pipefitters, and } \\
\text { Steamfitters }\end{array}$ & 29 \\
\hline Electricians & $\begin{array}{l}\text { Plumbers, Pipefitters, and } \\
\text { Steamfitters }\end{array}$ & $\begin{array}{l}\text { Heating, Air Conditioning, } \\
\text { and Refrigeration } \\
\text { Mechanics and Installers }\end{array}$ & 25 \\
\hline $\begin{array}{l}\text { Construction } \\
\text { Equipment Operators }\end{array}$ & $\begin{array}{l}\text { Drywall Installers, Ceiling } \\
\text { Tile Installers, and Tapers }\end{array}$ & Masonry Workers & 24 \\
\hline Carpenters & $\begin{array}{l}\text { Drywall Installers, Ceiling } \\
\text { Tile Installers, and Tapers }\end{array}$ & $\begin{array}{l}\text { Flooring Installers and Tile } \\
\text { and Marble Setters }\end{array}$ & 20 \\
\hline $\begin{array}{l}\text { Drywall Installers, } \\
\text { Ceiling Tile } \\
\text { Installers, and Tapers }\end{array}$ & Masonry Workers & Roofers & 12 \\
\hline Carpenters & $\begin{array}{l}\text { Painters, Construction and } \\
\text { Maintenance }\end{array}$ & Roofers & 12 \\
\hline $\begin{array}{l}\text { Plumbers, Pipefitters, } \\
\text { and Steamfitters }\end{array}$ & $\begin{array}{l}\text { Heating, Air Conditioning, } \\
\text { and Refrigeration } \\
\text { Mechanics and Installers }\end{array}$ & $\begin{array}{l}\text { Welders, Cutters, Solderers, } \\
\text { and Brazers }\end{array}$ & 10 \\
\hline
\end{tabular}

\section{Conclusions}

Multiskilling strategies have been investigated by analyzing skill sets of the construction job market using web scraping and text mining techniques. Based on skills required on job posting, desirable dual and triple skill set configurations were identified. These findings make a significant contribution to the existing body of knowledge in construction research by providing information that can support training programs for the construction industry and can counsel career paths for multiskilled laborers. Specifically, the construction industry can devise multiskilling or cross-training programs that can serve a broad body of workforce in the nation. Moreover, by developing the desirable skill set configurations aligning with the industry needs, multiskilled laborers can be exposed to more opportunities to get employed as well as construction companies can expect hiring adequate multiskilled laborers. The result of this research can be updated as further data is collected through web scraping and the proposed approach can keep providing up-to-date guidance of multiskilling strategies by considering trends and any changes of desirable skill sets posted on the website.

Although this study has limitations that it is difficult to detect any errors by people who posted job descriptions or multiple job descriptions on one post, this research harvested a large number of data points (228,242 jobs) from actual job postings from all over the U.S using a data-driven approach. This approach enabled us to identify the various skill sets from a large repository of construction job postings. This study also quantifies the extent of multiskilling as found in a big dataset of real construction job postings. 


\section{References}

Burleson, R. C., Haas, C. T., Tucker, R. L., \& Stanley, A. (1998). Multiskilled labor utilization strategies in construction. Journal of Construction Engineering and Management, 124(6), 480489.

Carley, L. A., Haas, C. T., Borcherding, J. D., \& Goodrum, P. M. (2003). Experiences with multiskilling among non-union craft workers in US industrial construction projects. Engineering, Construction and Architectural Management, 10(6), 374-381. https://doi.org/10.1108/09699980310509345

Gomar, J. E., Haas, C. T., \& Morton, D. P. (2002). Assignment and allocation optimization of partially multiskilled workforce. Journal of Construction Engineering and Management, 128(2), 103-109.

Haas, T. C., Rodriguez, A. M., Glover, R., \& Goodrum, P. M. (2001). Implementing a multiskilled workforce. Construction Management and Economics, 19(6), 633-641. https://doi.org/10.1080/01446190110050936

Indeed: Job Search https://www.indeed.com/

Kim, S., Chang, S., \& Castro-Lacouture, D. (2020). Dynamic Modeling for Analyzing Impacts of Skilled Labor Shortage on Construction Project Management. Journal of Management in Engineering, 36(1), 04019035. https://doi.org/doi.org/10.1061/(ASCE)ME.1943-5479.0000720

McKinsey \& Company. (2020). The next normal in construction.

Nasirian, A., Arashpour, M., Abbasi, B., \& Akbarnezhad, A. (2019). Optimal Work Assignment to Multiskilled Resources in Prefabricated Construction. Journal of Construction Engineering and Management, 145(4), 04019011. https://doi.org/10.1061/(asce)co.1943-7862.0001627

U.S. Bureau of Labor Statistics (U.S. BLS). (2020). Occupational Outlook Handbook. Retrieved from U.S. Bureau of Labor Statistics website: https://www.bls.gov/ooh/

Wang, Y., Goodrum, P. M., Haas, C. T., \& Glover, R. W. (2009). Analysis of Observed Skill Affinity Patterns and Motivation for Multiskilling among Craft Workers in the U.S. Industrial Construction Sector. Journal of Construction Engineering and Management, 135(10), 9991008. https://doi.org/10.1061/(asce)co.1943-7862.0000072

Wongwai, N., \& Malaikrisanachalee, S. (2011). Augmented heuristic algorithm for multi-skilled resource scheduling. Automation in Construction, 20(4), 429-445.

https://doi.org/10.1016/j.autcon.2010.11.012 